\title{
Model Cooperative Learning Tipe Make A Match Untuk Meningkatkan Hasil Belajar Dan Aktivitas Siswa
}

\author{
Rilda Weni \\ SDN 21 Batang Anai Kabupaten Padang Pariaman
}

\begin{abstract}
This study was conducted as solution for the low learning activity and achievement of 5th grade students at SDN 21 Batang Anai Kabupaten Padang Pariaman. The low learning activity and achievement of students was caused by teaching process which often to use expository method. This study is a classroom action research with two cycles aimed to improve students' learning activity and achievement by implementing one of cooperative learning model, i.e. make a match type. Subjects of this study are 5th grade students at SDN 21 Batang Anai. Mean of test score of students in cycle I is 60.00 and become 76.88 in cycle II. Students' learning activity was also improved. Thus, cooperative learning -make a match- can improve students' learning activity and achievement.
\end{abstract}

Kata Kunci: learning achievement, learning activity, bahasa, make a match Indonesian Institute for Counseling, Education and Therapy (IICET).

\section{PENDAHULUAN}

Pembelajaran adalah proses interaksi peserta didik dengan pendidik dan sumber belajar pada suatu lingkungan belajar. Pembelajaran merupakan bantuan yang diberikan pendidik agar dapat terjadi proses pemerolehan ilmu dan pengetahuan, penguasaan kemahiran dan tabiat, serta pembentukan sikap dan kepercayaan pada peserta didik. Dengan kata lain, pembelajaran adalah proses untuk membantu peserta didik agar dapat belajar dengan baik (Krisna, 2009). Gagne dan Briggs (dalam Krisna, 2009) mengatakan bahwa, pembelajaran adalah suatu sistem yang bertujuan untuk membantu proses belajar siswa, yang berisi serangkaian peristiwa yang dirancang, disusun sedemikian rupa untuk mempengaruhi dan mendukung terjadinya proses belajar siswa yang bersifat internal. Selain itu, Mashudi, dkk. (dalam Kurnia, 2010) pembelajaran adalah suatu kegiatan kompleks. Pembelajaran pada hakikatnya tidak hanya menyampaikan pesan, tetapi juga merupakan aktivitas profesional yang menuntut guru dapat menggunakan keterampilan dasar mengajar secara terpadu serta menciptakan situasi efisien. Oleh karena itu, dalam pembelajaran, guru perlu menggunakan strategi belajar yang menarik.

Karena aktivitas belajar banyak sekali macamnya, maka para ahli mengadakan klasifikasi atas macam-macam aktivitas; salah satunya yaitu: Paul Dierich (dalam Hamalik, 2007) membagi kegiatan belajar dalam 8 kelompok, yaitu kegiatan visual, kegiatan lisan, kegiatan mendengarkan, kegiatan menulis, kegiatan menggambar, kegiatan metrik, kegiatan mental, kegiatan emosional, dan minat. Hasil belajar adalah pola-pola perbuatan, nilai-nilai, pengertian, sikap-sikap apresiasi dan keterampilan. Dari hasil pemikiran Gagne, hasil belajar berupa: informasi verbal, yaitu kapabalitas mengungkapkan pengetahuan dalam bentuk bahasa, baik lisan maupun tertulis; keterampilan intelektual yaitu kemampuan mempresentasikan konsep dan lambang. Keterampilan intelektual terdiri dari kemampuan mengategorisasi, kemampuan analitis-sintetis fakta-konsep dan 
mengembangkan prinsip-prinsip keilmuan; strategi kognitif yaitu kecakapan menyalurkan dan mengarahkan aktivitas kognitifnya sendiri; keterampilan motorik, yaitu kemampuan melakukan serangkaian gerak jasmani dalam urusan dan koordinasi sehingga terwujud otomatisme gerak jasmani; sikap, yaitu kemampuan menerima atau menolak objek berdasarkan penilaian.

Bahasa memiliki peran sentral dalam perkembangan intelektual sosial dan emosional. Bahasa juga merupakan penunjang keberhasilan dalam mempelajari semua bidang studi. Pembelajaran bahasa diharapkan membantu siswa mengenal dirinya, budayanya dan budaya orang lain, mengemukakan gagasan dan perasaan, berpartisipasi dalam masyarakat yang menggunakan bahasa tersebut serta menggunakan kemampuan analitis dan imajinatif yang ada pada dirinya. Berdasarkan hasil observasi yang telah peneliti lakukan di kelas V SDN 21 Batang Anai Kabupaten Padang Pariaman, yaitu tentang pembelajaran Bahasa Indonesia diperoleh data bahwa selama ini guru hanya menggunakan metode ceramah dan tanya jawab dalam pembelajaran. Ini mengakibatkan aktivitas dan hasil pembelajaran siswa tidak meningkat, lemahnya daya berpikir siswa, kurangny kemampuan bekerja sama dengan teman. Tentu saja Kriteria Ketuntasan Minimal (KKM) yan sudah ditetapkan yaitu 70 tidak tercapai.

Salah satu cara meningkatkan aktivitas dan hasil pembelajaran Bahasa Indonesia di kelas V SDN 21 Batang Anai adalah melalui pembelajaran model cooperative learning tipe Make a Match. Pembelajaran model cooperative learning tipe Make a Match merupakan salah satu metode pembelajaran yang dapat meningkatkan aktivitas dan hasil belajar Bahasa Indonesia siswa, baik secara individu maupun kelompok. Artzt dan Newman (dalam Asma, 2009) mendefinisikan bahwa belajar kooperatif adalah suatu pendekatan yang mencakup kelompok kecil dari siswa yang bekerja sama sebagai suatu tim untuk memecahkan masalah, menyelesaikan suatu tugas, atau menyelesaikan suatu tujuan bersama. Proses pembelajaran pada model pembelajaran kooperatif antara lain memfasilitasi terjadinya interaksi antar peserta didik, antara peserta didik dengan guru, lingkungan, dan sumber belajar lainnya serta memfasilitasi peserta didik dalam pembelajaran kooperatif dan kolaboratif.

Menurut Suprijono (2009), salah satu tipe model pembelajaran kooperatif adalah Make a Match. Hal-hal yang perlu dipersiapkan jika pembelajaran dikembangkan dengan make a match adalah kartu-kartu. Kartu-kartu tersebut terdiri dari kartu berisi pertanyaan-pertanyaan dan kartukartu lainnya berisi jawaban dari pertanyaan-pertanyaan tersebut. Langkah berikutnya adalah guru membagi komunitas kelas menjadi 3 kelompok. Kelompok pertama merupakan kelompok pembawa kartu-kartu berisi pertanyaan-pertanyaan. Kelompok kedua adalah kelompok pembawa kartu-kartu berisi jawaban-jawaban. Kelompok ketiga adalah kelompok penilai. Dalam hal ini diatur posisi kelompok-kelompok tersebut berbentuk huruf $\mathrm{U}$, dan diupayakan kelompok pertama dan kedua berjajar saling berhadapan.

\section{METODE}

Jenis penelitian yang digunakan peneliti adalah Penelitian Tindakan Kelas (PTK). Secara etimologis, ada tiga istilah yang berhubungan dengan PTK, yakni penelitian, tindakan, dan kelas (Sanjaya, 2010). Penelitian ini dilaksanakan di kelas V SDN 21 Batang Anai, Kabupaten Padang Pariaman. Siswa kelas V berjumlah 20 orang, yang terdiri dari 10 orang laki-laki dan 10 orang perempuan. Dalam penelitian ini, peneliti menggunakan beberapa instrumen untuk mengumpulkan data, yaitu lembar observasi kegiatan pembelajaran, tes hasil belajar, dan catatan lapangan. Indikator keberhasilan dalam proses pembelajaran diukur dengan menggunakan persentase penilaian hasil belajar siswa dan Kriteria Ketuntasan Minimal (KKM). Indikator keberhasilan pada hasil belajar siswa yang akan dicapai adalah 70\%, dan KKM pada mata pelajaran Bahasa Indonesia adalah 70 . 


\section{HASIL}

\section{Deskripsi Siklus I}

\section{Perencanaan}

Sebelum menerapkan tindakan pada siklus I, peneliti melihat terlebih dahulu kondisi pembelajaran Bahasa Indonesia pada siswa kelas V SDN 21 Batang Anai, Kabupaten Padang Pariaman. Tindakan ini dilakukan untuk melihat kondisi awal, sehingga dapat dijadikan patokan terhadap adanya peningkatan proses pembelajaran setelah dilakukan tindakan. Selanjutnya, untuk memulai pembelajaran, terlebih dahulu peneliti menyiapkan rencana pelaksanaan pembelajaran (RPP). Selain mempersiapkan RPP, peneliti juga mempersiapkan lembar observasi aktivitas siswa dan lembar aktivitas guru serta catatan lapangan yang diisi pada setiap kali pertemuan.

\section{Pelaksanaan}

Siklus I terdiri dari tiga kali pertemuan. Dua kali pertemuan merupakan proses pembelajaran dan satu kali pertemuan ditujukan untuk tes. Setiap proses pembelajaran dilaksanakan dengan mengikuti tahapan pembelajaran kooperatif tipe make a match.

\section{Pengamatan}

1) Observasi Aktivitas Siswa

Data hasil observasi ini didapat melalui lembar observasi aktivitas siswa dan digunakan untuk melihat proses dan perkembangan aktivitas siswa yang terjadi selama pembelajaran berlangsung.

Tabel 1. Observasi Aktivitas Siswa pada Siklus I

\begin{tabular}{|c|c|c|c|c|c|}
\hline \multirow[t]{3}{*}{ Indikator } & \multicolumn{4}{|c|}{ Pertemuan } & \multirow[t]{3}{*}{ Rata-rata Persentase } \\
\hline & \multicolumn{2}{|c|}{$\mathrm{I}$} & \multicolumn{2}{|c|}{ II } & \\
\hline & Jumlah & $\%$ & Jumlah & $\%$ & \\
\hline $\mathbf{A}$ & 6 & 37,50 & 7 & 43,75 & $40,63 \%$ \\
\hline B & 9 & 56,25 & 10 & 62,50 & $59,38 \%$ \\
\hline $\mathbf{C}$ & 11 & 68,75 & 12 & 75,00 & $71,88 \%$ \\
\hline D & 10 & 62,50 & 11 & 68,75 & $65,63 \%$ \\
\hline Rata-rata & & 56,25 & & 62,50 & $59,38 \%$ \\
\hline
\end{tabular}

Keterangan:

1. Siswa menjawab pertanyaan guru (A)

2. Siswa bisa berdiskusi dengan teman (B)

3. Siswa mengerjakan LKS (individual) (C)

4. Siswa mengikuti diskusi dengan baik (sesuai aturan yang diberikan guru) (D)

\section{2) Observasi Aktivitas Guru}

Berdasarkan lembar observasi aktivitas guru dalam pembelajaran pada siklus I, maka jumlah skor dan persentase aktivitas guru dalam mengelola pembelajaran pada siklus I dapat dilihat pada tabel berikut.

Tabel 2. Observasi Aktivitas Guru pada Siklus I

\begin{tabular}{ccc}
\hline Pertemuan & Jumlah Skor & Persentase \\
\hline I & 9 & $60,00 \%$ \\
II & 10 & $66,67 \%$ \\
Rata-rata & 9 & $63,33 \%$ \\
\hline
\end{tabular}




\section{3) Hasil Belajar Siswa}

Tabel 3. Hasil Belajar Siswa pada Siklus I

\begin{tabular}{lcc}
\multicolumn{1}{c}{ Uraian } & Jumlah & Target \\
\hline Jumlah siswa yang mengikuti tes & 14 & 16 \\
Jumlah siswa yang tuntas tes & 8 & 14 \\
Jumlah siswa yang tidak tuntas tes & 6 & 4 \\
Rata-rata nilai tes & 60,00 & 70 \\
Persentase ketuntasan tes & $57,14 \%$ & $100 \%$ \\
\hline
\end{tabular}

\section{4) Catatan lapangan}

Berdasarkan catatan lapangan maka ditemukan bahwa ada beberapa orang siswa yang bertanya pada guru serta siswa mendengarkan pertanyaan dan jawaban yang dibacakan temannya di depan kelas (aktivitas audio visual).

\section{Refleksi}

Kegiatan refleksi dilakukan secara kolaboratif antara peneliti dan guru kelas yang dilakukan pada setiap akhir siklus. Refleksi siklus satu ini mencakup refleksi terhadap perencanaan dan pelaksanaan pembelajaran. Dari tahap perencanaan, peneliti mempersiapkan RPP, lembar observasi aktivitas siswa, aktivitas guru, dan catatan lapangan. Dalam tahapan ini, peneliti belum mempersiapkan dengan maksimal. Sedangkan kelemahan dalam pelaksanaannya, waktu yang ada belum terkoordinasi dengan baik sehingga dalam pelaksanaan ini guru harus merencanakan waktu dengan baik.

Dari hasil paparan siklus I diketahui bahwa aktivitas siswa masih belum sesuai seperti yang diharapkan. Hal ini terlihat dari keempat indikator, hanya satu di antaranya yang mencapai target, yaitu siswa mengerjakan LKS (secara individual) dengan rata-rata $71,88 \%$. Sedangkan indikator yang lainnya belum mencapai target, yaitu siswa menjawab pertanyaan guru hanya mencapai rata-rata 40,63\%. Kemudian untuk indikator siswa bisa berdiskusi dengan teman mencapai $68,75 \%$. Selanjutnya indikator siswa bisa mengikuti diskusi dengan baik mencapai rata-rata $65,73 \%$. Dapat disimpulkan bahwa penelitian pada siklus pertama masih jauh dari ketuntasan yang telah ditetapkan, terlihat pada rata-rata keseluruhan yaitu 59,38\%. Peneliti bersama kedua observer menyimpulkan bahwa masalah yang dihadapi peneliti dalam mengelola pembelajaran adalah sebagian dari langkah-langkah pada perencanaan terlaksana sesuai dengan yang diinginkan, tetapi terdapat beberapa langkah yang tidak berjalan dengan baik. Contohnya, guru kurang bisa membagi waktu untuk masingmasing langkah sehingga siswa kekurangan waktu dalam berdiskusi; guru kurang memberikan petunjuk dalam mengerjakan LKS; guru kurang mengawasi siswa dalam berdiskusi, sehingga masih ada siswa yang kurang berperan dalam diskusi kelompok. Kemudian guru masih menunjuk siswa yang sering aktif dan yang duduk di barisan depan saja, sedangkan siswa pada bagian belakang jarang diberikan kesempatan dalam menjawab pertanyaan guru, yang termasuk dalam indikator keberhasilan penelitian ini.

Untuk memperbaiki kelemahan dan mempertahankan kelebihan yang telah dicapai pada siklus I, maka pembelajaran pada siklus II dibuat perencanaan sebagai berikut: (1) Guru harus bisa membagi waktu untuk masing-masing langkah sehingga siswa tidak kekurangan waktu dalam berdiskusi; (2) Sebelum siswa berdiskusi hendaklah diberikan petunjuk yang jelas agar siswa tidak bingung dan bertanya-tanya lagi; (3) Guru hendaklah membimbing dan mengarahkan siswa dalam berdiskusi, agar siswa benar-benar aktif dalam mengerjakan dikusi. 


\section{Deskripsi Siklus II}

\section{Perencanaan}

Dari hasil refleksi siklus I diperoleh kesimpulan bahwa pembelajaran belum berjalan dengan efektif. Hal ini disebabkan oleh beberapa kelemahan dalam pelaksanaan melalui penggunaan model pembelajaran kooperatif tipe Make a Match. Permasalahan terjadi karena peneliti belum terampil menjalankan pembelajaran dan peneliti belum melaksanakan pembelajaran sesuai dengan alokasi waktu yang direncanakan. Berdasarkan hasil ini direncanakan perbaikan terhadap tindakan yang akan diterapkan pada siklus II, yaitu: (1) Lebih memperhatikan dan membimbing siswa dalam pelaksanaan pembelajaran untuk dapat aktif dalam pelaksanaan pembelajaran yaitu terutama pada aktivitas menjawab pertanyaan guru. (2) Lebih memotivasi siswa untuk giat dan serius dalam belajar melalui motivasi kepada siswa untuk bisa aktif dalam pembelajaran. (3) Lebih memperhatikan dan membimbing siswa dalam berdiskusi. (4) Merencanakan waktu dengan baik untuk melakukan diskusi. (5) Sebelum melaksanakan tes, siswa diminta untuk duduk di tempatnya masing-masing, sehingga tidak ada siswa yang bertanya dan berbagi jawaban. Selanjutnya peneliti menyiapkan RPP, lembar observasi aktivitas siswa dan lembar observasi kegiatan pembelajaran (aspek guru), serta catatan lapangan yang diisi setiap pertemuan.

\section{Pelaksanaan}

Pada siklus II ini peneliti melaksanakan tiga kali pertemuan. Pada pertemuan ketiga diadakan tes akhir siklus II.

\section{Pengamatan}

Pada siklus II ini, hasilnya lebih baik dibandingkan siklus sebelumnya. Di sini guru telah melaksanakan semua proses pembelajaran yang telah direncanakan dan telah menghasilkan hasil belajar yang optimal.

\section{1) Observasi Aktivitas Siswa}

Data hasil observasi ini didapat melalui lembar observasi aktivitas siswa dan digunakan untuk melihat proses dan perkembangan aktivitas siswa yang terjadi selama pembelajaran berlangsung.

Tabel 4. Observasi Aktivitas Siswa pada Siklus II

\begin{tabular}{|c|c|c|c|c|c|}
\hline \multirow[t]{3}{*}{ Indikator } & \multicolumn{4}{|c|}{ Pertemuan } & \multirow{3}{*}{$\begin{array}{l}\text { Rata-rata } \\
\text { Persentase }\end{array}$} \\
\hline & \multicolumn{2}{|c|}{$\bar{I}$} & \multicolumn{2}{|c|}{ II } & \\
\hline & Jumlah & $\%$ & Jumlah & $\%$ & \\
\hline $\mathbf{A}$ & 12 & 75,00 & 13 & 81,25 & $78,13 \%$ \\
\hline B & 13 & 81,25 & 14 & 93,75 & $87,50 \%$ \\
\hline $\mathrm{C}$ & 14 & 93,75 & 15 & 96,80 & $95,28 \%$ \\
\hline D & 13 & 81,25 & 14 & 93,75 & $87,50 \%$ \\
\hline Rata-rata & & 82,81 & & 91,39 & $87,10 \%$ \\
\hline
\end{tabular}

\section{Keterangan:}

1. Siswa menjawab pertanyaan guru (A)

2. Siswa bisa berdiskusi dengan teman (B)

3. Siswa mengerjakan LKS (individual) $(\mathrm{C})$

4. Siswa mengikuti diskusi dengan baik (sesuai aturan yang diberikan guru) (D)

\section{2) Data hasil observasi aktivitas guru}

Berdasarkan lembar observasi aktivitas guru dalam pembelajaran pada siklus I, maka jumlah skor dan persentase aktivitas guru dalam mengelola pembelajaran pada siklus II dapat dilihat pada tabel berikut. 
Tabel 5. Observasi ktivitas Guru pada Siklus II

\begin{tabular}{ccc}
\hline Pertemuan & Jumlah Skor & Persentase \\
\hline I & 13 & $86,66 \%$ \\
II & 14 & $93,33 \%$ \\
Rata-rata & 12 & $89,50 \%$ \\
\hline
\end{tabular}

Dari tabel di atas dapat dibuat analisis bahwa persentase guru dalam mengelola pembelajaran memiliki rata-rata persentase $89,50 \%$ sehingga dapat dikatakan bahwa kegiatan guru dalam mengajar sudah baik dari target yang ditetapkan.

\section{3) Hasil Belajar Siswa}

Berdasarkan hasil tes siklus I, persentase siswa yang tuntas dan rata-rata skor tesnya dapat dilihat pada tabel berikut.

Tabel 6. Ketuntasan dan Rata-rata Hasil Tes Siswa pada Siklus II

\begin{tabular}{lcc}
\hline \multicolumn{1}{c}{ Uraian } & Jumlah & Target \\
\hline Jumlah siswa yang mengikuti tes & 26 & 26 \\
Jumlah siswa yang tuntas tes & 24 & 26 \\
Jumlah siswa yang tidak tuntas tes & 2 & 3 \\
Rata-rata nilai tes & 76,88 & 70 \\
Persentase ketuntasan & $87,50 \%$ & $100 \%$ \\
\hline
\end{tabular}

Mencermati tabel di atas dan apabila dibandingkan dengan siklus I, maka siklus II ini jauh lebih baik, 16 siswa yang ikut tes 24 orang siswa sudah tuntas diatas KKM yaitu siswa yang dapat nilai 90 ada 4 orang, yang dapat 80 ada 5 orang, yang mendapat nilai 70 ada 5 orang sedangkan yang mendapat 60 ada 2 orang. Hal ini terlihat pada persentase ketuntasan belajar dan rata-rata skor tes. Pada siklus I terdapat 57,14 \% dengan rata-rata nilai tes 60,00 siswa. Sedangkan pada siklus II, terdapat 87,50\% siswa yang tuntas belajar dengan rata-rata skor tes 76,88. Dapat ditarik kesimpulan bahwa pada siklus II siswa sudah dapat dikatakan tuntas belajar secara klasikal dan rata-rata skor tes juga meningkat dari siklus I ke siklus II. Hal ini menunjukkan tercapainya target pembelajaran yang diinginkan, terlampir.

\section{4) Catatan lapangan}

Berdasarkan catatan lapangan maka ditemukan ada satu orang siswa yang mengemukakan pendapat pada saat pembelajaran dan siswa juga bertanya kepada temannya tentang materi pelajaran.

\section{Refleksi}

Refleksi dilakukan untuk mengetahui apakah tindakan pada siklus II sudah berhasil atau belum. Jika belum maka penelitian dilanjutkan pada siklus berikutnya. Berdasarkan hasil pengamatan, pembelajaran sudah terlaksana dengan baik. Siswa sudah bisa belajar dengan baik dengan Model Pembelajaran Kooperatif tipe Make a Match. Dilihat dari data persentase aktivitas dan hasil tes siklus II siswa, maka sudah tercapai target yang ditetapkan dan keberhasilan belajar sangat baik. Sedangkan data pengamatan aktivitas guru dalam mengelola pembelajaran sudah mengalami peningkatan dibandingkan pada siklus I, dan dapat dikatakan cukup baik. Berdasarkan analisis data yang telah diuraikan di atas, maka disimpulkan bahwa peningkatan hasil pembelajaran Bahasa Indonesia di kelas V pada siklus II sudah meningkat dan karena itu diputuskan untuk tidak melanjutkan penelitian pada siklus berikutnya. Dengan demikian penelitian ini telah selesai. 


\section{PEMBAHASAN}

Penelitian tindakan kelas ini terdiri dari dua siklus yang setiap siklusnya terdiri dari tiga pertemuan. Model pembelajaran yang digunakan pada penelitian ini adalah Model Pembelajaran Kooperatif tipe Make a Match. Penelitian ini menggunakan instrumen penelitian berupa lembar observasi aktivitas siswa, penilaian terhadap guru dalam mengelola pembelajaran, dan catatan lapangan. Pembelajaran dengan menggunakan Model Pembelajaran Kooperatif tipe Make a Match merupakan hal baru bagi siswa, sehingga dalam pelaksanaannya siswa mengalami banyak perubahan cara belajar. Bisanya siswa mendapatkan materi hanya dari apa yang diterangkan guru, sehingga siswa pasif dalam belajar dan sedikit sekali interaksi.

Aktivitas siswa pada siklus I belum sesuai dengan indikator yang telah ditetapkan. Karena pembelajaran menggunakan Model Pembelajaran Kooperatif tipe Make a Match merupakan hal baru bagi siswa. Oleh karena itu siswa masih belum paham bagaimana cara berdiskusi menggunakan Model Pembelajaran Kooperatif tipe Make a Match tersebut. Dari pertemuan pertama siklus I, disimpulkan bahwa aktivitas siswa masih di bawah rata-rata, namun pada siklus II siswa sudah dapat menunjukkan aktivitas yang baik secara keseluruhan, yang pada akhirnya akan meningkatkan hasil pembelajaran Bahasa Indonesia di kelas V SDN 21 Batang Anai, Kabupaten Padang Pariaman. Hal tersebut dapat dijelaskan sebagai berikut.

\section{Aktivitas Siswa}

Hal yang paling mendasar dituntut dalam proses pembelajaran adalah aktivitas siswa. Aktivitas siswa dalam proses pembelajaran merupakan interaksi antara guru dan siswa ataupun siswa itu sendiri sehingga suasana belajar menjadi segar dan kondusif. Hal ini dapat dilihat dari persentase rata-rata aktivitas siswa pada tabel berikut.

Tabel 7. Observasi Aktivitas Siswa pada Siklus I dan Siklus II

\begin{tabular}{llll}
\hline No & Indikator Aktivitas Siswa & \multicolumn{2}{c}{ Rata-rata Persentase } \\
\cline { 3 - 4 } & & Siklus I & Siklus II \\
1. & Siswa menjawab pertanyaan guru & $40,63 \%$ & $78,13 \%$ \\
2. & Siswa bisa berdiskusi dengan teman & $62,50 \%$ & $87,50 \%$ \\
3. & Siswa mengerjakan LKS & $75,00 \%$ & $95,28 \%$ \\
4. & Siswa mengikuti diskusi dengan baik & $62,50 \%$ & $87,50 \%$ \\
Rata-rata kedua siklus & $59,38 \%$ & $87,10 \%$ \\
\hline
\end{tabular}

Berdasarkan tabel di atas dapat disimpulkan bahwa pada pembelajaran Bahasa Indonesia dengan menggunakan Model Pembelajaran Kooperatif tipe Make a Match yang dilaksanakan dapat ditingkatkan aktivitas siswa. Hal ini terbukti dari kenaikan rata-rata persentase untuk masing-masing indikator keberhasilan aktivitas siswa yang telah ditetapkan. Aktivitas siswa pada siklus I sudah bisa dikatakan meningkat, tetapi masih belum mencapai kriteria ketuntasan yang ditetapkan. Pada siklus II, aktivitas siswa sudah dalam kategori baik, siswa sudah banyak melakukan indikator A, B, C, dan D. Walaupun untuk indikator (A) masih tergolong cukup, namun sudah mengalami peningkatan untuk setiap kali pertemuan.

\section{Aktivitas Guru}

Keberhasilan siswa dalam pembelajaran pada umumnya dilihat juga dari pengelolaan pelaksanaan pembelajaran pada persentase aktivitas guru. Dalam hal ini terlihat peningkatan pengelolaan pembelajaran menggunakan Model Pembelajaran Kooperatif tipe Make a Match pada tabel berikut. 
Tabel 8. Observasi Aktivitas Guru pada Siklus I dan Siklus II

\begin{tabular}{cc}
\hline Siklus & Rata-rata per Siklus \\
\hline I & $63,33 \%$ \\
II & $89,50 \%$ \\
\hline
\end{tabular}

Dari tabel di atas dapat disimpulkan bahwa pelaksanaan pembelajaran Bahasa Indonesia dengan menggunakan Model Pembelajaran Kooperatif tipe Make a Match pada siklus I diperoleh rata-rata persentase $63,33 \%$, dan ini dapat dikatakan kurang dari ketuntasan yang peneliti tetapkan. Hal ini disebabkan guru belum terbiasa membawakan pembelajaran dengan menggunakan Model pembelajaran kooperatif tipe make a match dan baru pertama kali peneliti cobakan. Pada siklus II, rata-rata persentase $89,50 \%$, dan ini dapat dikatakan sangat baik, sehingga pelaksanaan pembelajaran Bahasa Indonesia dengan menggunakan model pembelajaran kooperatif tipe Make a Match sudah jauh meningkat dari siklus I.

\section{KESIMPULAN}

Rata-rata persentase pada indikator siswa menjawab pertanyaan guru mengenai materi pelajaran dengan baik di siklus I yaitu 40,63\%, pada siklus II naik menjadi $78,13 \%$. Rata-rata persentase pada indikator siswa bisa berdiskusi dengan teman pada siklus II meningkat menjadi $87,50 \%$ dari sebelumnya pada siklus I hanya $62,50 \%$. Rata-rata persentase pada indikator siswa mengerjakan pekerjaan sekolah/latihan secara individu (berupa LKS) di siklus I yaitu 75,00\%, pada siklus II naik menjadi $95,28 \%$. Rata-rata persentase pada indikator siswa mengikuti diskusi dengan baik (sesuai aturan yang diberikan guru) di siklus I yaitu 62,50\%, pada siklus II naik menjadi $87,50 \%$. Dari penjabaran di atas, dapat disimpulkan bahwa rata-rata aktivitas dan hasil pembelajaran siswa pada siklus I hanya mencapai $62,50 \%$, namun pada siklus II meningkat menjadi 87,50\%. Dengan kata lain, aktivitas dan hasil pembelajaran Bahasa Indonesia melalui Model Pembelajaran Kooperatif tipe Make a Make di kelas V SDN 21 Batang Anai meningkat.

Hasil pembelajaran siswa berdasarkan tabel hasil belajar, yaitu pada siklus I, persentase ketuntasan belajar siswa baru mencapai $57,14 \%$ dan nilai rata-rata hasil belajar siswa hanya 60,00. Persentase ketuntasan belajar siswa belum mencapai target yang peneliti tetapkan yaitu $70 \%$. Sedangkan pada siklus II, persentase ketuntasan siswa sudah mencapai 87,50\%; dan nilai rata-rata hasil belajar sudah di atas KKM 70, yaitu 76,88. Dari perbandingan kedua siklus tersebut, terdapat peningkatan hasil belajar siswa, pada siklus II persentase ketuntasan siswa sudah melebihi target yang ditetapkan, berarti target penelitian telah tercapai. Bagi guru, pelaksanaan pembelajaran melalui Model Pembelajaran Kooperatif tipe Make a Match dapat dijadikan salah satu alternatif variasi dalam pelaksanaan pembelajaran. Disarankan kepada peneliti berikutnya yang menggunakan tipe Make a Match agar kartu-kartu pertanyaan dan jawaban menggunakan gambar, tidak hanya menggunakan kalimat.

\section{DAFTAR RUJUKAN}

Arikunto, Suharsimi. (2011). Penelitian Tindakan Kelas. Cetakan ke-9. Jakarta: Bumi Aksara.

Asma, Nur. (2009). Model Pembelajaran Kooperatif. Padang: UNP Press.

Bungin, Burhan. (2003). Analisis Data Penelitian Kualitatif. Jakarta: Grafindo Persada.

Depdiknas. (2006). Kurikulum Tingkat Satuan Pendidikan. Jakarta: BNSP.

Hamalik, Oemar. (2011). Proses Belajar Mengajar. Cetakan ke-12. Jakarta: Bumi Aksara

Moneter, Marla. (2008). "Peningkatan Proses Pembelajaran IPS melalui Model Cooperative Learning Tipe Make a Macth di Kelas V SDN 06 Surabayo, Kabupaten Agam”. Skripsi. Padang: Universitas Bunghatta. 
Sanjaya, Wina. (2010). Penelitian Tindakan Kelas. Jakarta: Kencana.

Suprijono, Agus. (2010). Cooperative Learning: Teori \& Aplikasi Paikem. Yogyakarta: Pustaka Pelajar. 